\title{
Nilai Budaya dalam Cerita Rakyat Toraja
}

\author{
Ratnawati*) \\ Balai Bahasa Ujung Pandang
}

\begin{abstract}
Abstrak
Toraja adalah salah satu suku yang mendiami wilayah pegunungan di Sulawesi Selatan. Penduduknya yang berjumlah sekitar 450.000 jiwa masih tinggal di Kabupaten Toraja Induk dan Kabupaten Toraja Utara. Umumnya, penduduk ini menganut agama Kristen, sebagian lagi memeluk agama Islam, serta sebagiannya lagi masih ada yang menganut kepercayaan animisme yang dikenal dengan Aluk To Dolo. Kepercayaan Aluk To Dolo inilah yang mendasari pelaksanaan berbagai upacara yang memerlukan persembahan hewan kurban dalam jumlah nominal tinggi dalam kehidupan masyarakat Toraja.

Tulisan ini memaparkan nilai budaya dalam Cerita Rakyat Toraja. Nilai budaya yang menonjol dalam Cerita Rakyat Toraja sebagian besar dipengaruhi oleh kepercayaan Auk To Dolo yang mencakupi hubungan manusia dengan Sang Pencipta, hubungan manusia dengan alam, hubungan manusia dengan sesama manusia, dan hubungan manusia dengan dirinya sendiri.

Tulisan ini bertujuan menambah wawasan tentang kebudayaan Toraja yang selanjutnya dapat meningkatkan pemahaman terhadap salah satu kebudayaan yang ada dan berkembang di Sulawesi Selatan.
\end{abstract}

Kata Kunci: Nilai budaya, Cerita Rakyat Toraja

\section{Pendahuluan}

Sastra dan kebudayaan, baik sebagai satu kesatuan, maupun secara terpisah, yaitu 'sastra' dan 'kebudayaan' selalu dikaitkan dengan nilai-nilai positif. Artinya, sastra dan kebudayaan, yang dengan sendirinya dihasilkan melalui aktivitas manusia itu sendiri, berfungsi untuk meningkatkan kehidupan. Karya sastra sebagai katharsis (Aristoteles), aesthetic function (Mukarovsky), lango (Zoetmulder), aktivitas manusia sebagai pencerahan (abad Pertengahan), dan berbagai

\footnotetext{
*) Magister Pendidikan, Pembantu Pimpinan pada Balai Bahasa Ujung Pandang
} 
definisi sastra sebagai hiburan, pada dasarnya menunjuk pada fungsi kemanusiaan tersebut (Ratna, 2005:9).

Usaha pembinaan dan pengembangan kebudayaan nasional tidak dapat dilepaskan dengan upaya penggalian sumber-sumber kebudayaan daerah yang banyak tersebar di seluruh pelosok nusantara. Dalam konteks ini, kebudayaan daerah merupakan sumber potensial bagi terwujudnya kebudayaan nasional, sekaligus memberi corak dan karakteristik kepribadian bangsa.

Cerita rakyat merupakan bagian integral dari sastra pada umumnya terutama sastra daerah yang ada dan berkembang di nusantara ini. Ia tumbuh dan berkembang di tengah-tengah masyarakat penikmatnya. Cerita rakyat umumnya dituturkan dan hanya tersimpan dalam ingatan orang-orang tua atau pencerita. Namun, sekarang ini tidak sedikit pula cerita rakyat itu ada yang sudah ditulis, bahkan diterbitkan.

Cerita Rakyat Toraja, seperti halnya sastra daerah lain, juga berkembang secara lisan dari satu generasi ke generasi berikutrnya. Sastra daerah ini tetap terpelihara oleh masyarakatnya karena mereka yakin bahwa di dalamnya sarat dengan nilai-nilai luhur yang sangat bermanfaat bagi kehidupan umat manusia.

Pengungkapan nilai-nilai budaya dalam cerita rakyat perlu dilakukan agar nilai-nilai luhur yang ada dalam suatu masyarakat dapat diketahui oleh masyarakat lain sehingga dapat meningkatkan saling pengertian antarmasyarakat. Selain itu, nilai-nilai budaya bagi generasi muda dapat menjadi filter terhadap unsur-unsur luar yang belum tentu menguntungkan. 


\section{Pembahasan}

\subsection{Eksistensi Cerita Rakyat}

Cerita Rakyat Toraja bagi masyarakat Toraja tidak hanya untuk didengar dan diceritakan secara turun-temurun, tetapi juga cerita itu dianggap pernah terjadi pada masa lampau sehingga dapat memengaruhi tingkah laku mereka. Jadi, mereka taat kepada larangan/perintah yang berkaitan dengan cerita itu, misalnya mengapa dilarang bertengkar kalau sedang menumbuk padi, mengapa kayu cendana pantang dijadikan sebagai kayu bakar, mengapa dilarang menunjuk pelangi dengan jari telunjuk, mengapa kerbau putih pantang dimakan, dan sebagainya.

Selain itu, cerita juga berkaitan erat dengan lingkungan alam sekitarnya. Sejumlah cerita menampilkan nama-nama tempat dan gunung, atau mengapa sesuatu diberi nama demikian. Benda-benda berupa batu dan benda pusaka seperti emas, kain selendang, cangkul, dan lain-lain dianggap sebagai bukti kebenaran cerita.

Pada beberapa cerita, penutur meyakini bahwa apa yang diungkapkan dalam cerita itu benar-benar terjadi. Tokoh-tokoh cerita yang dipercayai kebenarannya dianggap sebagai leluhur yang menurunkan anak cucu dari generasi zaman lampau ke generasi berikutnya yang dengan penuh keajaiban menghadapi tantangan hidup.

Menurut William R. Bascom (dalam Abdullah, 1999:3--4), cerita rakyat dapat dibagi ke dalam beberapa golongan besar, yaitu:

a. Mite adalah cerita yang oleh masyarakat pemiliknya dipercaya sebagai sesuatu yang sungguh-sungguh terjadi pada zaman dahulu. Mite diajarkan untuk dipercaya karena dianggap memiliki kekuatan untuk menjawab ketidaktahuan, keragu-raguan, atau ketidakpercayaan dan sering dikaitkan dengan teknologi dan ritual. Mite merupakan perwujudan dogma dan biasanya dianggap suci. 
b. Legenda adalah cerita yang dianggap benar-benar terjadi, baik oleh pencerita maupun oleh pendengarnya. Waktu kejadiannya di zaman yang lebih muda. Legenda dapat bersifat sekuler atau suci dan tokoh utamanya adalah manusia.

c. Dongeng dianggap sebagai cerita rekaan, tidak dianggap sebagai dogma atau sejarah, dan tidak dipermasalahkan kebenaran tentang kejadian peristiwanya, sering hanya untuk hiburan, tetapi memiliki fungsi penting seperti dikesankan oleh dongeng-dongeng yang mengandung nasihat. Dongeng tidak terikat tempat dan waktu, berkisah tentang kehebatan peri dan dewa, tentang petualangan manusia dan binatang.

Berdasarkan pendapat tersebut, Cerita Rakyat Toraja digolongkan ke dalam tiga bentuk, yaitu mite, legenda, dan dongeng.

Cerita Rakyat Toraja biasanya dituturkan secara lisan pada berbagai kesempatan, yaitu (1) pada waktu pelaksanaan pesta adat seperti pesta kematian, pesta pengucapan syukur, dan pesta perkawinan; (2) pada waktu ada pertemuan, misalnya pertemuan di balai desa, pertemuan rumpun keluarga, dan pada waktu mempersiapkan penyambutan tamu (pembesar) secara adat; (3) pada saat mengadakan kerja bakti massal atau pada saat dalam perjalanan sebagai perintang-rintang waktu; dan (4) pada waktu seseorang menanyakan asal-usul suatu benda, nama tempat, sejarah perjuangan daerah, hubungan Tana Toraja dengan kerajaan yang ada di Sulawesi Selatan pada zaman dahulu, dan sejarah perjanjian Tana Toraja dengan daerah lainnya. 


\subsection{Nilai Budaya}

Nilai budaya adalah konsep abstrak mengenai masalah dasar yang sangat penting dan bernilai dalam kehidupan manusia (KBBI, 2008:963). Sejalan dengan definisi tersebut, Koentjaraningrat (1984:25) mengatakan bahwa nilai budaya itu adalah tingkat pertama kebudayaan ideal atau adat. Nilai budaya adalah lapisan paling abstrak dan luas ruang lingkupnya. Tingkat ini adalah ide-ide yang mengonsepsikan hal-hal yang paling bernilai dalam kehidupan masyarakat. Selain itu, sistem nilai terdiri atas konsepsi yang hidup dalam alam pikiran sebagian besar warga masyarakat mengenai hal-hal yang harus mereka anggap bernilai dalam kehidupan. Oleh karena itu, suatu sistem nilai budaya biasanya berfungsi sebagai pedoman tertinggi bagi perilaku manusia.

Nilai budaya dalam cerita rakyat dapat diketahui berdasarkan tema dan amanat yang terkandung dalam cerita tersebut. Selain itu, nilai juga dapat diketahui dari para tokoh yang berperan di dalam cerita itu.

\subsection{Nilai Budaya dalam Cerita Rakyat Toraja}

Nilai budaya dalam Cerita Rakyat Toraja dapat dibedakan ke dalam empat golongan besar, yaitu yang berkaitan dengan hubungan manusia dengan Sang Pencipta, hubungan manusia dengan alam, hubungan manusia dengan sesama manusia, dan hubungan manusia dengan dirinya sendiri. Berikut ini dipaparkan keempat hal tersebut.

\subsubsection{Nilai Budaya yang Berkaitan dengan Hubungan Manusia dengan Sang Pencipta}

Dalam hubungan dengan Sang Pencipta, masyarakat Toraja bersumber pada kepercayaan Aluk Todolo. Berdasarkan ajaran Aluk Todolo, kesatuan alam ini dengan segala isinya mempunyai kewajiban 
mengabdi dan memuja Tuhan yang menciptakannya yaitu kepada tiga hal, yaitu:

a. Puang Matua adalah sebagai Sang Pencipta semesta alam yang tertinggi dan yang paling utama.

b. Deata-Deata adalah sebagai pemelihara seluruh ciptaan Puang Matua. Deata terbagi atas tiga golongan, yaitu Deata Tangngana Langi (Sang pemelihara di langit, yaitu dewa yang menguasai seluruh isi langit dan cakrawala. Yang kedua, Deata Kapadanganua (Sang pemelihara permukaan bumi) yaitu dewa atau deata yang menguasai seluruh apa yang terdapat di atas muka bumi. Yang ketiga, Deata Tangngana Padang (Sang pemelihara isi bagian tengah tanah) yaitu dewa yang menguasai isi tanah, laut dan sungai.

c. Tomembali Puang atau biasa disebut tololo sebagai sang pengawas dan pemberi berkat kepada manusia turunannya.

Hal tersebut ditampilkan dalam dua cerita seperti berikut ini.

Iamoto ke memalaqi tu Aluk Todolo dao Toraya todiomai sae lako totemo belanna mangkamo napondok nenek todolon tu allo pura di bokoq. (Serreq Datu, 1986:184)

Itulah sebabnya orang yang masih memeluk Aluk Todolo selalu melaksanakan kegiatan pemujaan kepada dewa yang memberi rezeki kepada umat manusia.

Dao tanete todayang ke makaren-karen tontongbang tu Gonggang tikuqbiq-kuqbiq puduqna mukkun mangngando sia mssambayang langngan .... (Gonggang ri Sadoqkoq, 1986:119) 
Di bukit Todayang setiap sore gonggang dengan mulut komat-kamit mengucapkan mantra, memanjatkan doa ke hadapan Sang Pencipta ....

Berdasarkan kepercayaan tersebut, ketiga hal itu harus disembah/dipuja dengan tingkat dan cara yang berbeda, yaitu:

a. Pemala langngan Puang matua artinya pemujaan dan persembahan kepada sang pencipta sebagai upacara pemujaan dan persembahan yang paling tinggi yang harus dilakukan dengan kurban persembahan berupa kerbau, babi, dan ayam.

b. Pemala lako deata artinya pemujaan dan persembahan kepada sang pemelihara sebagai upacara yang menengah harus dilakukan dengan kurban persembahan babi dan ayam

c. Pemala lako Tomembali Puang/Todolo artinya pemujaan dan persembahan kepada Sang Pengawas Manusia turunannya sebagai upacara yang rendah yang harus dilakukan dengan kurban persembahan babi atau ayam.

Secara eksplisit cara pemujaan ditampilkan sebagai berikut.

Indeto nani umpogauq kapemalaran mangngando langnga Totumampana nasorongngi tu susinna:

Bolu sitammu uraqna

Kalosi ponno isinna

Kapoq maqdua lallang

Manuk sukku maelona (Gonggang ri sadoqkoq, 1986:119-120) 
Pada saat-saat tertentu di sana ia melaksanakan upacara pemujaan memajatkan doa ke hadapan Puang Pakombong dengan menyajikan antara lain sebagai berikut.

Daun sirih yang bertemu uratnya

Buah pinang yang bernas

Kapur sirih yang putih bersih

Ayam yang tak bercacat cela

Kepercayaan Aluk Todolo juga mendasari pelaksanaan berbagai upacara yang dibedakan atas dua golongan besar, yaitu Rambu Tukaq berupa upacara keselamatan dan pengucapan syukur dan Rambu Soloq berupa upacara kematian/pemakaman.

Berikut ini beberapa upacara Rambu Tukaq dalam Cerita Rakyat Toraja.

a. Upacara kelahiran

Anna maqaluk todolopa tu tomatuanna, inang lao lako toq bubun maqpiong. (Sadukung, 1986:197)

Demikian pula dalam memperingati hari kelahiran anak, bagi penganut aluk todolo masih berlaku kebiasaan pergi ke pinggir sumur untuk mengadakan sesajen berupa lemang.

b. Upacara syukuran karena ternaknya berkembang biak Inan dukato den pissan napogauqi Gonggang kapemalaran disanga "Massambeq Tedong" iamo tu maqkurre sumangaq belanna tontongbang membaqkaq tu tedongna. Lan kapemalaran 
iate billaq tu dipake unniraq dukuq manuk. (Gonggang ri Sadoqkoq, 1986:121)

Di tempat ini suatu waktu Gonggang mengadakan upacara massambeq tedong (upacara syukuran karena kerbau sudah berkembang biak dengan menggunakan billaq (sembilu) untuk mengiris daging ayam yang dijadikan sesajen.

c. Upacara pengakuan dosa

Iatu penassananna Pasauq napopaqbutti iamo maqbuaq untunna tedong namangngaku langnga totumpana. (Saleq sola Pasauq, 1986:148)

Sebagai bukti penyesalan itu, Pasauq mengadakan upacara maqbua dan di dalam pesta itu ia dengan jujur mengakui dosanya serta memohon ampun kepada Tuhan Mahakuasa.

d. Berbagai macam pesta adat

Belangna kasugiranna tau lan tondok iato, pembudami umpogauq kapemalaran susinna: maqtadoran, massuraq tallang, maqparekke para, murauk, laqpaq kasalle, metangdoq, sia pemalaran pengaqna. (Padang di Rura, 1986: 142)

Karena kekayaan mereka itu berlebihan dan serba berkecukupan, akhirnya mereka sering mengadakan pesta adat secara besarbesaran seperti maqtadoran, massuraq tallang, maqparekke para, merauk, laqpaq kasalle, metangdoq, dan lain-lain. 
Jika dibandingkan dengan upacara rambu tukaq, sepertinya masyarakat Toraja lebih mengagungkan upacara rambu soloq. Berikut ini upacara Rambu Soloq dalam Cerita Rakyat Toraja.

a. Upacara kematian

Upacara ini diungkapkan dalam beberapa cerita, yaitu dalam cerita Bunga Alluq dan Dolitau, Sangbidang, Babuqsolong, Massudilalong dan Lebonna, Batu Tomate, serta Bokkoqbokkoq. Salah satu kutipan upacara kematian sebagai berikut.

Gannaq pentallun ditambai tu Sokko namebali, diraqtag kuтua ia tu Babuqsolong patalomo lako siuluqna. Belanna ia te siuluqna, tedong lana tunuanmo indoqna tu natanggaq anna natalomo Babuqsolong, maqkatampakanna Babuqsolong mannamo umpantunuanni tu indoqna tonna dialuk. Dadi ia tu siuluqna taeqmo tedong natunuan indoqna belanna puramo natalo Babuqsolong

Setelah tiga kali berturut-turut nama Sokko mebali dipanggil dan selalu menyahut, diputuskanlah bahwa Babuqsolong menang dan kerbau sebanyak enam puluh empat ekor untuk pesta almarhum ibunya di lapangan upacara adalah miliknya semua. Jadi, kerbau saudarasaudaranya untuk persediaan pesta ibunya sudah habis semuanya. Akhirnya, hanyalah Babuqsolong sendiri yang memenuhi kewajiban sebagai anak yang mengabdi kepada kematian ibunya karena dia sendirilah yang dapat memotong kerbau dalam pesta itu. 
Dalam kepercayaan Aluk Todolo dikenal juga Pemali Sukaran Aluk (Larangan-Larangan dan pantangan dalam aturan-aturan agama)

a. Larangan untuk bertengkar pada saat menumbuk padi Iamoto namepasan tu tomatua nakua taeq naden sigaga kelangkiqlu toq issong belanna taeq namembaqkaq tu boqboq. Napasan duka tomatua kumua matakuq tu dalleq tama banua kesigagabangngi tu tau lan banua. (Anak Yatim Piatu, 1986:149)

Itulah sebabnya orang-orang tua selalu berpesan kepada anakanaknya atau cucunya bahwa kalau sedang menumbuk padi jangan sekali-kali bertengkar karena beras itu tidak mau bertambah atau pun berkembang dan rezeki tidak mau datang.

b. Pantangan mengucapkan kata-kata tertentu

Berikut ini kutipan-kutipan dalam dua cerita, yaitu Polo Padang, Datu Lumuran yang mengisahkan tentang pantangan mengucapkan kata-kata tertentu.

Mebalimi Polo Padang nakua, "Kamu poleq sola tallu tu sae umpepurai dalleku ke bongi. Dadi inang malolo tu Puang Matua, totemo lakupobaineko." Nakuami tinde adak dara, masussakan sibali tolino iatu tolino biasa ia manglambe sia mekambullung. (Polo Padang, 1986:125-126)

Polo padang mengatakan bahwa Tuhan Maha Adil, rupanya kamulah yang selalu menghabiskan tanamanku setiap malam. Sekarang aku ingin menikahimu. Putri menjawab, "Agaknya 
sukar bagi kami kawin dengan manusia karena manusia kadangkadang mengucapkan kata-kata tabu yang pantang bagi kami.

Tirambanni tu ambeqna diong sulluk natangmengkilala nasimpolo maqkada nakua, "wa, pida Pasuloan ungkatteneinaq." ...Ia te katangmekilalanna Batara Kassa male mengkaranduk lako Datu Lumuran .... (Datu Lumuran, 1986:106-107).

Dengan tidak sadar, Batara Kassa tiba-tiba berteriak, "Wah, Pida, Pasuloan mengencingi saya." .... Batara Kassa yang sudah terlanjur melanggar pantangan Datu Lumuran menyampaikan permohonan ampun, tetapi tidak diterima ....

\subsubsection{Nilai budaya yang berkaitan dengan hubungan manusia dengan alam}

Berkaitan dengan alam, masyarakat Toraja mengenal tiga alam, yaitu alam atas, alam tengah, alam bawah. Hal tersebut terdapat dalam pembagian tugas deata (Dewa), yaitu Deata-Deata sebagai pemelihara seluruh ciptaan Puang matua. Deata terbagi atas tiga golongan, yaitu Deata tangngana Langi (Sang pemelihara di langit, yaitu dewa yang menguasai seluruh isi langit dan cakrawala. Yang kedua, Deata Kapadanganua (sang pemelihara permukaan bumi) yaitu dewa ata deata yang menguasai seluruh apa yang terdapat di atas muka bumi. Yang ketiga, Deata Tangngana Padang (Sang pemelihara isi bagian tengah tanah) yaitu dewa yang menguasai isi tanah, laut dan sungai.

a. Dunia atas, yang dikuasai oleh Deata tangngana Langi dalam cerita dapat dikutip sebagai berikut. 
Umbai paqporainnamo Puang ungkombong langiq na lino, anna sirampean tolino tu anak tampakku, laqbiraka sipadadiammo batiq. Tanglatapomadiong pena, apa belanna torro tolino ia dadi lasule sola tallui rokko lino anna digenteq tomanurun di langiq, tosongloq di batara. (PPG 1986:128-129)

Tuhan telah menjodohkan anakku yang bungsu dengan Polo Padang dari bumi sehingga tidak boleh diceraikan oleh siapa pun juga. Karena Polo padang dari manusia dari bumi maka mereka bertiga akan kembali ke bumi dan mereka inilah yang disebut tomanurung, artinya orang diturunkan ke bumi.

b. Dunia bawah, yang dikuasai Deata Tangngana Padang dalam cerita dapat dikutip sebagai berikut.

Tikaririk bongi buqtumi tu tau diong mai Tokengko umpeparei tu pare. Natiroi Marampio Padang taqpa narok doke bulawan nasampe tu bulawan lamkalena. Attu ia dukato larimi iatu tau rokko pagtana. (Marampio padang sola Datu Nakkaq, 1986:170)

Pada malam harinya Marampio Padang ini pergi menunggui padinya. Tiada berapa lama menunggu, munculah orang melalui lubang dari bawah bumi (manusia dunia bawah) mencuri padinya itu.

Apa iate Datu Lumuran mebali nakua, "Apa tu mupokadanna apa taeqbang nalamaqdin dadi, belanna tantu muissan sia lamutandai kumиa; iate tau akute ludiongnaqpi toq mata wai naya tu iko daoko menggantananna." Mebali Batara Kassaq, 
“mentuqna tu alasanmu taeqnasang kuporai sangngadinna inang lakupobaineko.” (DLM, 1986: 106)

Datu lumuran menjawab, “apa yang kamu harapkan mustahil terjadi. Dunia kita berbeda, saya hidup di dalam air, sedangkan kamu hidup di darat." Batara Kassa menjawab, "Saya tidak peduli semua itu. Yang penting engkau harus menjadi istriku."

\subsubsection{Nilai budaya yang berkaitan dengan hubungan manusia dengan manusia lain}

Nilai budaya yang berkaitan dengan hubungan antara satu pihak dengan pihak lain dalam cerita, yaitu setia pada janji, tolong-menolong, menghormati tamu.

a. Setia pada janji

Berikut ini tanda kesetiaan pada janji yang diungkapkan oleh seorang pria dalam bentuk ucapan bahkan dibuktikan dengan cara bunuh diri.

Kитиа, pura bassemoq Lebonna, mangka sibole-bole

Pada tuo, pada mate

Pada sangrontaq inaya, pada ditambuttanai

Naia tu Lebonna, masai allomo manteqna

Rontaq rondon tobatangna

Lamentiromoko tau, mengkita sanda mairiq

Lamanteq todamoq aku, lasangrontaq inaamoq

(Massudilalong sola Lebonna, 1985:140)

Bahwa aku telah berjanji dengan Lebonna

Sehidup semati dan sepenanggungan

Satu lubang kami berdua 
Lebonna telah pergi

Dia sudah mendahului

Sekarang kamu menyaksikan, yang hadir jangan kaget

Sekarang aku berangkat, menyusul dia yang lebih dahulu

\section{b. Tolong-menolong}

Tolong-menolong merupakan sikap terpuji dan patut dicontoh dalam menerapkan suatu konsep kehidupan yang damai sejahtera. Makhluk sebagai ciptaan hadir dengan segala kelebihan dan kekurangan masingmasing. Oleh karena itu, sepatutnyalah dalam kehidupan ini kita menggunakan kelebihan yang dimiliki untuk membantu pihak lain. Pada gilirannya nanti, kelemahan kita akan ditutupi oleh kelebihan pihak lain. Nilai tolong-menolong dalam cerita dapat diketahui lewat kutipan berikut.

Naupuiqmi donga nakua, "Lasiangkarangkiq kedenkiq nerampoi sussa, susinnato kenalambinduqkanaq paqdiq baqtu kedenkiq nerampoi sussa (tattiuq sola donga, 1986:109)

Selanjutnyam rusa itu mengungkapkan bahwa apabila ada di antara mereka yang kena musibah atau kesusahan, maka kedua pihak harus saling menolong dan merasakannya bersama-sama.

c. Menghormati tamu

Menghormati tamu dalam cerita dapat diketahui berdasarkan kutipan berikut ini.

"Apara kamu mipogauq nasusira te tu kasugiranmi." Nakuami tinde pia biung, "Memalaq-malaq bangkan belanna den tau sae inde banuangki, iamo kipemalaqi.” (Serreg Datu, 2986:284) 
"Apa gerangan yang kamu perbuat sehingga kamu menjadi kaya?" Jawab anak yatim itu, "Kami haya menghormati dan melayani dengan sungguh-sungguh kalau ada orang yang datang di rumah kami."

\subsubsection{Nilai budaya yang berkaitan dengan hubungan manusia dengan dirinya sendiri}

Nilai budaya yang berkaitan dengan hubungan manusia dengan dirinya yaitu kerja keras dan sabar.

a. kerja keras

Mepasanmi tu ambeqna nakua, "Pemeloibangmi tu tengkamu lako lalan den oupaq musalamaq rampo lako tu lamuninna undakaq kande. Manarangkiq ussaro mase lako tau. Mebalikiq keditambaikiq, sia dituruq sola didama kenasuakiq tau.

Namentuqnato rakkaq sangpulota umpatuokiq diolu padangna tau sia ditiro melo kementengkakiq den oupaq naden salamaq. (Sadoqdongna, 1986:162)

Berkatalah ayahnya, "Baik-baiklah dalam perjalanan, semoga engkau selamat tiba di tempat tujuan. Pandai-pandailah engkau menarik hati orang. Menyahutlah bila engkau dipanggil dan rajinlah mengerjakan apa yang diperintahkan. Buruk baik nasib yang engkau alami terletak pada kedua belah tanganmu. Ikutlah perbuatan yang baik sehingga kamu mendapat keberuntungan dan keselamatan." 
b. sabar

Moi susito, ia tu Matadua saqbaraqbang dikkag. Ia kedisengkei kappabang dikkaq. (Tallu Tosiunuq, 1986:179)

Namun demikian, si Mata Dua tetap sabar bahkan kalau dimarahi oleh orang tuanya, ia tetap tenang dan diam saja.

\section{Penutup}

Cerita Rakyat Toraja bagi masyarakat Toraja tidak hanya untuk didengar dan diceritakan secara turun-temurun, tetapi juga cerita itu dianggap pernah terjadi pada masa lampau sehingga dapat memengaruhi tingkah laku mereka.

Sesuai dengan analisis yang dilakukan terhadap Cerita Rakyat Toraja disimpulkan nilai budaya dalam Cerita Rakyat Toraja yang berkaitan dengan hubungan manusia dengan sang Pencipta dan hubungan manusia dengan alam sebagian besar didasarkan pada kepercayaan Aluk Todolo. Berikut ini cakupan nilai budaya yang berkaitan dengan empat hubungan, yaitu:

a. Hubungan manusia dengan Sang Pencipta berupa kewajiban memuja dan menyembah, tata cara pemujaan, upacara keselamatan dan kematian, serta larangan/pantangan yang harus dijauhi;

b. Hubungan manusia dengan alam berupa alam atas, alam tengah, dan alam bawah;

c. Hubungan manusia dengan sesama manusia berupa kesetiaan terhadap janji, tolong menolong, dan menghormati tamu;

d. Hubungan manusia dengan dirinya sendiri berupa kerja keras dan sabar. 


\section{Daftar Pustaka}

Koentjaraningrat. (1984). Kebudayaan, Mentalitas, dan Pembangunan. Jakarta: PT Gramedia

L.T. Tangdilintin. (1974). Toraja dan Kebudayaannya. Ujung Pandang: Kantor Cabang II Lembaga Sejarah dan Antropologi

(1978). Sejarah dan Pola-Pola Hidup Toraja. Tana Toraja: Yayasan Lepongan Bulan

Ratna, Nyoman Kutha. (2005). Sastra dan Cultural Studies. Yogyakarta: Pustaka Pelajar

Sikki, Muhammad et al. (1986). Struktur Cerita Rakyat Toraja. Jakarta: Pusat Pembinaan dan Pengembangan Bahasa.

Tim Penyusun Kamus Pusat Bahasa. (2008). Kamus Besar Bahasa Indonesia. Jakarta: PT Gramedia Pustaka Utama 